\title{
Low body mass index increases risk of anemia in patients with HIV-AIDS receiving antiretroviral therapy
}

\author{
Mirna Widiyanti*, Reynold Ubra**, and Eva Fitriana*
}

\begin{abstract}
BACKGROUND
In acquired immunodeficiency syndrome (AIDS) cases, cytopenias of all major blood cell lines were increasingly recognized in patients with HIV infection. Anemia commonly occurs during HIV infection and has been associated with increased progression to AIDS and decreased survival. The aim of this study was to determine the prevalence of anemia and associated risk factors in adults with HIV-AIDS receiving antiretroviral therapy (ART).
\end{abstract}

\section{METHODS}

A cross sectional study was conducted involving 90 adults with HIVAIDS. Socio demographic data were collected using a questionnaire. In all patients, $\mathrm{CD}^{+}$lymphocyte counts were performed by means of a PIMA analyzer, while hemoglobin was determined using a Sysmex hematology analyzer. The WHO cut-off value of hemoglobin was adjusted to altitude to define anemia. Mild to moderate anemia was defined as hemoglobin 8-13 $\mathrm{g} / \mathrm{dL}$ for men and 8-12 $\mathrm{g} / \mathrm{dL}$ for women. Severe anemia was defined as hemoglobin $8 \mathrm{~g} / \mathrm{dL}$. Data was analyzed by using logistic regression test.

\section{RESULTS}

There were 90 subjects with HIV-AIDS in this study. Anemia was found in 50 subjects $(55.6 \%)$, consisting of $12.2 \%$ with mild anemia and $43.4 \%$ with moderate to severe anemia. Multiple logistic regression showed that an important risk factor for anemia was low body mass index (BMI) between $<17-18.5(\mathrm{OR}=4.20 ; 95 \% \mathrm{CI}=1.23-14.36)$. However, the $\mathrm{CD} 4<350$ cells $/ \mathrm{mm} 3$ was not a significant risk factor for anemia $(\mathrm{OR}=1.03 ; 95 \% \mathrm{CI}=0.21-5.04)$.

\section{CONCLUSIONS}

Low BMI increases the risk of anemia in subjects with HIV receiving ART. Better screening for anemia and infectious diseases and modified harm reduction strategy are primary needs in HIV patients.
*Institute of Research and

Development for Biomedicine Papua

**Mimika AIDS Commision

\section{Correspondence :}

Mirna Widiyanti

Institute of Research and

Development For Biomedicine Papua Ministry of Health,

Republic of Indonesia

Jl. Kesehatan No.10 Dok II Jayapura

Phone: (+62967) 534389

Fax (+62967) 534697

Mobile: +6281344388000

Email: ninawidhy@gmail.com

Date of first submission, April 3, 2017

Date of final revised submission,

November 27, 2017

Date of acceptance, November 27, 2017

This open access article is distributed under a Creative Commons AttributionNon Commercial-Share Alike 4.0 International License

Cite this article as: Widiyanti M, Ubra R, Fitriana E. Low body mass index increases risk of anemia in adults with HIV-AIDS receiving antiretroviral therapy. Univ Med 2017;36:221-7. doi: 10.18051/UnivMed.2017.v36.221 227

Keywords: Anemia, body mass index, CD4 ${ }^{+}$, HIV-AIDS 


\section{INTRODUCTION}

Acquired immune deficiency syndrome (AIDS) is an infectious disease caused by the human immunodeficiency virus (HIV), a retrovirus that attacks and destroys T-helper lymphocytes $\left(\mathrm{CD}^{+}\right)$, resulting in an immunocompromised condition of the patient. HIV causes a decrease in the body's immunity and increases the incidence of various cognitive impairment and AIDS dementia. ${ }^{(1)}$ HIV-AIDS cases in Indonesia continue to increase and until 2014 the number reached 150285 cases of HIV, while AIDS cases reached 55 799. The number of HIV cases in Papua reached 16051 and in Timika regency reached $3900 .^{(2)}$

Anemia is one of the most common blood abnormalities in persons with HIV disease. Up to $90 \%$ of adults can develop anemia during an HIV infection, especially individuals with advanced disease and low CD4 ${ }^{+} \mathrm{T}$-cell count. Persons with anemia have a decreased quality of life that potentially increases the chance of mortality. The incidence of anemia has been found to be strongly associated with the progression of HIV to AIDS. ${ }^{(3,4)}$ Even among persons initiating antiretroviral therapy, anemia has been demonstrated to be a strong risk factor for disease progression and subsequent death independent of CD4 count and viral load. ${ }^{(5)}$

Several causes of anemia have been described in HIV-positive patients, such as changes in cytokine production with subsequent effect on hematopoiesis, decreased erythropoietin concentration, opportunistic infections agents such as Mycobacterium avium complex and administration of chemotherapeutic agents such as zidovudine and ganciclovir. ${ }^{(6)}$

The more advanced the disease the higher the incidence of anemia and also the morbidity and mortality. Anemia has been proved to be an independent risk factor for death. According to the World Health Organization (WHO) mild to moderate anemia is defined as hemoglobin 8$13 \mathrm{~g} / \mathrm{dL}$ for men and 8-12 g/dL for women.
Severe anemia is defined as hemoglobin $8 \mathrm{~g} /$ dL. (7)

According to a study in sub-Saharan Africa, which has the largest burden of HIV in the world, anemia is common as patients are more likely to be malnourished, have severe immunosuppression, and higher rates of comorbidities (especially tuberculosis and malaria) than those in high-income countries. ${ }^{(8)}$

A study in Iran on the prevalence of anemia and related factors in HIV positive patients showed that among $212 \mathrm{HIV}$ positive patients the proportion of anemia was $71 \%$, with the majority of patients having mild to moderate anemia, while 17 patients $(8 \%)$ had a positive history of tuberculosis. The investigators found a strong association between anemia and death..$^{(9)}$ A cross sectional study in India showed that proper etiological diagnosis could be reached in 46 patients. Among them the correlation between $\mathrm{Hb} \%$ and $\mathrm{CD} 4$ count was statistically nonsignificant $(p=0.074, r=0.47)$ whereas it was significant between absolute lymphocyte and CD4 counts $(\mathrm{p}=0.006, \mathrm{r}=0.41) .{ }^{(10)}$

The major cause of anemia is impaired erythropoiesis resulting from the release of inflammatory cytokines and decreased production of hematopoietic growth factors, coupled with malabsorption and impaired recycling of iron.

This study aimed to determine the prevalence of anemia and the risk factors associated with the incidence of anemia in HIV patients receiving antiretroviral (ARV) therapy.

\section{METHODS}

\section{Research design}

An analytic cross sectional study was conducted on HIV/AIDS patients undergoing routine care at Mitra Masyarakat Hospital, Mimika, Papua, from March-May 2015.

\section{Research subjects}

The study was conducted by reviewing hospital data of patients who were receiving 
highly active antiretroviral therapy (HAART) at the HIV clinic of Mimika. The sample size was estimated using a single population formula, $3 \%$ level precision (d) with $95 \%$ confidence interval. Patients who were pregnant at baseline or during the follow up visits were excluded from the study.

\section{Measurements}

A detailed history including sociodemographic characteristics, presenting symptoms, presence of symptoms related to anemia, nutritional history, past medical history, previous and current drug history, caretaker characteristics (including education level and occupation) was assessed with a pretested and standardized questionnaire.

After the interview, a detailed review of the medical records of all subjects was performed, noting such details as concurrent opportunistic infections and WHO clinical staging of HIV disease. Blood samples for determination of hemoglobin level and $\mathrm{CD}^{+}{ }^{+}$count were collected and processed.

\section{Laboratory analysis}

Three $\mathrm{mL}$ of venous blood was collected from the median cubital vein of each subject by an experienced laboratory technologist for CD4+ count determination using a Pima analyzer (Alere, Germany) and for hemoglobin determination using a hematology analyzer (Sysmex, Japan).

Anemia was defined based on hematological reference values for anemia for the adult Indonesian population. Accordingly, mild to moderate anemia was defined as a hemoglobin concentration of 8-13 g/dL for men and $8-12 \mathrm{~g} / \mathrm{dL}$ for women. Severe anemia was defined as hemoglobin $8 \mathrm{~g} / \mathrm{dL}$.

The CD4 count was reported as the number of CD4 cells present in $1 \mathrm{~mm}^{3}$ of blood (cells/ $\mathrm{mm}^{3}$ ). The classification of CD4 cell counts of $<350$ cells $/ \mathrm{mm}^{3}$ and $\geq 350$ cells $/ \mathrm{mm}^{3}$ was based on the WHO recommendation that HIV patients starting ARV therapy should be patients with CD4 $<350$ cells $/ \mathrm{mm}^{3}$. ${ }^{(11)}$

\section{Statistical analysis}

Logistic regression analysis was used to analyze the data, and odds ratio with $95 \%$ confidence interval was used to quantify the strength of association between anemia and its potential predictors. A p-value of less than 0.05 was considered significant.

\section{Ethical clearence}

This study was conducted after obtaining approval from the ethical commission of the National Institute of Health Research and Development, Ministry of Health, under number: LB.02.01/5.2/KE/156/2015

\section{RESULTS}

Table 1 shows that among HIV-positive respondents in Mimika, 25 (27.8\%) were male while $65(72.2 \%)$ were female. The largest age group of $<35$ years consisted of 55 subjects $(61.1 \%)$ and the group of $>35$ years comprised 35 (38.9\%). HIV patients who were ethnic Papua consisted of 65 (72.2\%) individuals, while ethnic non-Papuans consisted of 25 (27.8\%) individuals. With respect to educational level, there were more individuals who had been enrolled in school i.e. $81.1 \%$, compared to $18.9 \%$ who had not attended school. Most HIV-positive individuals (75 individuals or $83.3 \%$ ) were employed, compared with $16.7 \%$ who were nonemployed. HIV-positive respondents who were married comprised 80 individuals (88.9\%), whereas unmarried respondents comprised 10 individuals (11.1\%). Nearly all respondents (83 individuals or $92.2 \%$ ) had heterosexual risk factors and only $7(7.8 \%)$ had other risk factors. According to clinical characteristics, the number of subjects at clinical stage III/IV was 74 individuals (82.2\%) and at clinical stage I and II 16 individuals (17.8\%). The CD4 count of $>350$ cells $/ \mathrm{mm}^{3}$ included a total of 71 individuals (78.9\%), body mass index (BMI) of 18.5-25 comprised $70(77.8 \%)$ individuals. The prevalence of anemia was $50(55.6 \%)$. A total of 74 patients $(82.2 \%)$ had tuberculosis as 
Table 1. Socio-demographic and clinical characteristics and ART duration in HIV subjects $(\mathrm{n}=90)$

\begin{tabular}{|c|c|c|}
\hline Variable & $\mathbf{n}$ & $\%$ \\
\hline \multicolumn{3}{|l|}{ Gender } \\
\hline Male & 25 & 27.8 \\
\hline Female & 65 & 72.2 \\
\hline \multicolumn{3}{|l|}{ Ethnicity } \\
\hline Papua & 65 & 72.2 \\
\hline Non-Papua & 25 & 27.8 \\
\hline \multicolumn{3}{|l|}{ Age (years) } \\
\hline$<35$ & 55 & 61.1 \\
\hline$\geq 35$ & 35 & 38.9 \\
\hline \multicolumn{3}{|l|}{ Educational status } \\
\hline No education & 17 & 18.9 \\
\hline Education & 73 & 81.1 \\
\hline \multicolumn{3}{|l|}{ Employment status } \\
\hline Yes & 75 & 83.3 \\
\hline No & 15 & 16.7 \\
\hline \multicolumn{3}{|l|}{ Marital status } \\
\hline Never married & 10 & 11.1 \\
\hline Married & 80 & 88.9 \\
\hline \multicolumn{3}{|l|}{ Risk factor } \\
\hline Heterosexual & 83 & 92.2 \\
\hline Other & 7 & \\
\hline \multicolumn{3}{|c|}{ WHO clinical stage } \\
\hline Stage I/ II & 74 & 82.2 \\
\hline Stage III/IV & 16 & 17.8 \\
\hline \multicolumn{3}{|c|}{ CD4 cell count (cells $\left./ \mathrm{mm}^{3}\right)$} \\
\hline$<350$ & 19 & 21.1 \\
\hline$\geq 350$ & 71 & 78.9 \\
\hline \multicolumn{3}{|c|}{ Body mass index $\left(\mathrm{kg} / \mathrm{m}^{2}\right)$} \\
\hline$<17-18.5$ & 20 & 22.2 \\
\hline $18.5-25$ & 70 & 77.8 \\
\hline \multicolumn{3}{|l|}{ Anemia } \\
\hline Yes & 50 & 56.7 \\
\hline No & 40 & 43.3 \\
\hline \multicolumn{3}{|c|}{ Opportunistic infection } \\
\hline Tuberculosis & 74 & 82.2 \\
\hline Other & 16 & 17.8 \\
\hline \multicolumn{3}{|l|}{ Therapy } \\
\hline AZT-based & 58 & 64.4 \\
\hline & 32 & 35.6 \\
\hline \multicolumn{3}{|c|}{ Duration of therapy (months) } \\
\hline$<24$ & 31 & 34.4 \\
\hline$\geq 24$ & 59 & 65.6 \\
\hline
\end{tabular}

AZT $=$ Azidothymidine (Zidovudine)

opportunistic infection. The duration of azidothymidine treatment of $>24$ months was found in $59(65.6 \%)$ subjects. The relationship between gender and the incidence of anemia showed that there was no significant difference between the percentages of anemia in males and females $(p=0.237)$. Similarly, for the variables age, marital status, risk factors, opportunistic infections, clinical staging and therapy, there was no significant relationship with the occurrence of anemia $(p>0.05)$. The variables that showed a significant association with anemia were BMI (OR: 4.23; 95\% CI: 1.28-13.94) and CD4 count (OR: 3.52; 95\% CI: 1.31-9.69) (Table 2).

Table 3 shows the logistic regression model with anemia as the dependent variable and body mass index and numbers of $\mathrm{CD}^{+}$cells as independent variable. The results of the analysis showed that the risk of anemia in HIV subjects with low BMI was 4.20 times higher compared to those with normal BMI (OR: $4.10 ; 95 \% \mathrm{CI}$ : 1.23-14.36). Subjects with low $\mathrm{CD}^{+}$count $\left(<350\right.$ cells $\left./ \mathrm{mm}^{3}\right)$ had a 1.03 times higher risk for anemia compared to subjects with $\mathrm{CD}_{4}$ counts of $\geq 350$ cells $/ \mathrm{mm}^{3}$, but the relationship was statistically not significant (OR:1.03; 95\% CI: 0.21-5.04).

\section{DISCUSSION}

Our study showed that the prevalence of anemia among HIV-infected patients in Timika was $55.6 \%$. This result is in line with another study at Hasan Sadikin hospital as the referral hospital for HIV in West Java, showing that the prevalence of anemia among HIV-infected patients was $49.6 \% .^{(12)}$ However, this prevalence is higher than the prevalence of anemia among HIV-infected patients in South Africa of $18.0 \% .^{(5)}$

Since hemoglobin measurements are simple and inexpensive, monitoring hemoglobin levels over the first 6 months of ART among patients at high risk of anemia may allow for improved detection of HIV-related anemia.

A cross-sectional study showed that the prevalence of anemia in HIV-AIDS patients is prominent and that the important risk factors for anemia are oral candidiasis and CD4, while BMI and administration of ARV drugs are protective factors. ${ }^{(13)}$

Research in South India reported an anemia prevalence of $22 \%$ in patients with CD $4>500$ cells / $\mathrm{mm} 3$, while the prevalence increased to 
Table 2. Association of socio-demographic and other clinical variables with anemia among HIV subjects $(\mathrm{n}=90)$

\begin{tabular}{|c|c|c|c|c|}
\hline Variables & Anemic & Non-anemic & p value & OR $(95 \% \mathrm{CI})$ \\
\hline \multicolumn{5}{|l|}{ Gender } \\
\hline Male & 11 & 14 & 0.237 & $0.52(0.21-1.33)$ \\
\hline Female & 39 & 26 & & \\
\hline \multicolumn{5}{|l|}{ Age (years) } \\
\hline$<35$ & 32 & 23 & 0.664 & $1.31(0.56-3.08)$ \\
\hline$\geq 35$ & 18 & 17 & & \\
\hline \multicolumn{5}{|c|}{ Body Mass Index $\left(\mathrm{kg} / \mathrm{m}^{2}\right)$} \\
\hline$<17-18,5$ & 16 & 4 & $0.020^{*}$ & $4.23(1.28-13.94)$ \\
\hline $18.5-25$ & 34 & 36 & & \\
\hline \multicolumn{5}{|l|}{ Marital status } \\
\hline Married & 45 & 35 & 0.746 & $1.28(0.34-4.79)$ \\
\hline Not married & 5 & 5 & & \\
\hline \multicolumn{5}{|l|}{ Risk factor } \\
\hline Heterosexual & 46 & 37 & 1.000 & $0.93(0.19-4.43)$ \\
\hline Other & 4 & 3 & & \\
\hline \multicolumn{5}{|c|}{ Opportunistic infection } \\
\hline Tuberculosis & 42 & 32 & 0.782 & $1.31(0.49-3.87)$ \\
\hline Other & 8 & 8 & & \\
\hline \multicolumn{5}{|c|}{ WHO clinical stage } \\
\hline Stage I/II & 40 & 34 & 0.590 & $0.70(0.23-2.14)$ \\
\hline Stage III/IV & 10 & 6 & & \\
\hline \multicolumn{5}{|l|}{ CD4 cell count } \\
\hline$<350$ & 27 & 10 & $0.005^{*}$ & $3.52(1.31-9.69)$ \\
\hline$\geq 350$ & 23 & 30 & & \\
\hline \multicolumn{5}{|l|}{ Therapy } \\
\hline AZT-based & 33 & 25 & 0.826 & $1.16(0.48-2.77)$ \\
\hline Other & 17 & 15 & & \\
\hline \multicolumn{5}{|c|}{ Duration of therapy (months) } \\
\hline$<24$ & 18 & 13 & 0.825 & $1.16(0.48-2.81)$ \\
\hline$\geq 24$ & 32 & 27 & & \\
\hline
\end{tabular}

$60 \%$ in patients with CD $<100$ cells $/ \mathrm{mm} 3$. This study concluded that anemia is associated with severe immune suppression in subjects with HIV infection. ${ }^{(14)}$

In addition, studies in 11 sub-Saharan African countries showed that in HIV-infected women the mean anemia prevalence was $56.7 \%$, with a range between 33 and $2 \% .^{(15)}$ Ramezani et al. ${ }^{(16)}$ in Iran found that mild-tomoderate hemoglobin concentrations between 8-14 g/dL was present in $46 \%$ of HIV-infected patients, but there was no difference between anemic and non-anemic patients in terms of age, sex, stage of disease, CD4 and antiretroviral treatment.

We also found that low BMI increased the risk of anemia. This result was in line with the results of the study in South Africa showing that low BMI was associated with anemia in HIV subjects. ${ }^{(5)}$ The association between anemia and low BMI is likely to reflect malnutrition, as a number of nutritional deficiencies contribute to anemia. The association of anemia with low BMI is of specific relevance to India, where the rate of chronic malnutrition is among the highest in the world. ${ }^{(17)}$ Interestingly, even

Table 3. Factors associated with anemia resulting from multiple logistic regression analysis

\begin{tabular}{cccccc} 
& \multirow{2}{*}{ B } & p value & Adjusted & \multicolumn{2}{c}{ 95\% CI OR } \\
\cline { 4 - 6 } & & & OR & Lower & Upper \\
\hline CD4 & 0.037 & 0.963 & 1.03 & 0.21 & 5.04 \\
BMI & 1.436 & 0.022 & 4.20 & 1.23 & 14.36 \\
\hline
\end{tabular}


individuals with a normal BMI had a two and half times increased odds of anemia as compared to those who were overweight. Low BMI is associated with many nutrient deficiencies including iron, folate and B12 that contribute directly to anemia. The increased risk in anemia among patients with immunosuppresion is in agreement with previous published reports. ${ }^{(18)}$

Our study found that low CD4+ cell count was not a risk factor for anemia in HIV subjects. Another study in Mexico found different results, i.e. that low $\mathrm{CD} 4+$ cell count was positively correlated with hemoglobin level in HIV subjects. ${ }^{(19)}$

It was postulated that, apart from immunological status and viral load, other factors might play major roles in the pathogenesis of anemia. Detecting normocytic normochromic morphology as the major type of anemia was in tune with the existing data. Despite conflicting reports worldwide, in a few studies strong correlation has been shown between absolute lymphocyte and CD4 counts. ${ }^{(20)}$ Therefore the absolute lymphocyte count can sometimes be used as a surrogate marker of immunological status in ART naive HIV patients, particularly in resource poor areas.

Being on an AZT containing regimen was also a risk factor for developing anemia. Studies have shown the short-term tolerability related to the use of AZT, in particular the development or worsening of anaemia. ${ }^{(21)}$

Finally, the high prevalence of anemia in patients with CD4 cell counts of $<200$ cells $/ \mu 1$ has implications for the choice of initial HAART regimen in developing countries. Since anemia is an adverse effect of zidovudine (AZT), use of this drug is contraindicated in patients with preexisting anemia. ${ }^{(22)}$

The main limitation of this analysis is its cross sectional design, which precludes definite determination of the temporal relationship between anemia and its associated factors. Also, our database does not capture laboratory findings that could clarify the frequency of anemia due to particular nutrient deficiencies.
Other inflammatory parameters such as Creactive protein (CRP), interleukin-6 (IL-6), and tumor necrosis factor alpha (TNF-alpha) should be studied as well in the future.

\section{CONCLUSION}

Low BMI increases the risk of anemia in subjects with HIV. Better screening for anemia is the primary need in HIV patients.

\section{CONFLICT OF INTEREST}

There was no conflict of interest between the authors and the study subjects

\section{ACKNOWLEDGEMENTS}

This study was supported financially by the Institute of Health Research and Development for Biomedicine Papua, Ministry of Health, Republic of Indonesia. We also acknowledge all the staff who assisted with blood and data collection at Mitra Masyarakat Hospital, Mimika, Papua.

\section{CONTRIBUTORS}

MW designed the study and was involved in sampling and performing the experiment. MW, EF interpreted the data. MW, EF, RU+ contributed to writing and finalizing the manuscript. All authors read and approved the manuscript.

\section{REFERENCES}

1. Sharp PM, Hahn BH. Origins of HIV and the AIDS pandemic. Cold Spring Harb Perspect Med 2011;1: $1-22$.

2. Direktorat Jenderal Pemberantasan Penyakit Menular dan Penyehatan Lingkungan. 2014 Statistik kasus HIV/AIDS di Indonesia. Jakarta: Kementerian Kesehatan RI;2014.

3. Kulkarni MB, Bhalerao MM, Mungal SU, et al. Anemia in subjects living with HIV/AIDS: a cross sectional study from India. IOSR J Dent Med Sci 2015;14:4-8. 
4. Ndlovu Z, Chirwa T, Takuva S. Incidence and predictors of recovery from anemia within an HIVinfected South African cohort 2004-2010. Pan African Med J 2014;19:114-20.

5. Takuva S, Maskew M, Brennan AT, et al. Anemia among HIV-infected patients initiating antiretroviral therapy in South Africa: improvement in hemoglobin regardless of degree of immunosuppresion and the initiating ART regimen. J Trop Med 2013. Article ID 162950.

6. Jam S, Ramezani A, Sabzvari D, et al. A crosssectionel study of anemia in human immunodeficiency virus-infected patients in Iran. Arch Iranian Med 2009; 12:145-50.

7. World Health Organization. Hemoglobin concentrarion for the diagnosis of anemia and assesment of severity. Geneva: World Health Organization;2011.

8. World Health Organization. Worldwide prevalence of anemia 1993-2005: WHO global database on anemia. Geneva: World Health Organization;2008.

9. Meidani M, Rezaei F, Maracy MR, et al. Prevalence, severity, and related factors of anemia in HIV/AIDS patients. J Res Med Sci 2012;17:13842.

10. Pande A, Bhattacharyya M, Pain S, et al. Anemia in antiretroviral naive HIV/AIDS patients: a study from Eastern India. J Health Allied Sci 2011;10:14.

11. World Health Organization. WHO issues new HIV recommendations calling for earlier treatment. Geneva : World Health Organization;2013.

12. Wisaksana R, Sumantri R, Indrati AR, et al. Anemia and iron homeostasis in a cohort of HIV-infected patients in Indonesia. BMC Infect Dis 2011;11:213.

13. Sumantri R, Wicaksana R, Ariantana AR. Prevalensi dan faktor risiko anemia pada HIVAIDS. MKB 2009;41:187-92.
14. Subbaraman R, Anemia among HIV-infected in South India [dissertation]. New Haven: The Yale University of Medicine;2007.

15. Bradley SEK, Mishra V. HIV and nutrition among women in sub-Saharan Africa. DHS Analytical Studies No. 16. Calverton, Maryland, USA: Macro International Inc.;2008.

16. Ramezani A, Aghakhan A, Sharif MZ, et al. Anemia prevalence and related factors in HIV-infected patients; a cohort study. Iranian J Phathol 2008;3: 128-8.

17. Gragnolati M, Shekar M, Gupta M. India's undernourished children: a call for reform and action. Washington, D.C : The World Bank ; 2005.

18. Takuva S, Louwagie G, Zuma K, et al. Durability of first line antiretroviral therapy: reasons and predictive factors for modification in a Swaziland cohort. J Antivir Antiretrovir 2012;4:14-20.

19. Mata-Marin JA, Gaytan-Martinez JE, MartinezMartinez RE, et al. Risk factors and correlates for anemia in HIV treatment-naïve infected patients: a cross-sectional analytical study. BMC Res Notes 2010;3:230.

20. Alavi SM, Ahmadi F, Farhadi M. Correlation between total lymphocyte count, hemoglobin, hematocrit and CD4 count in HIV/AIDS patients. Acta Medica Iranica 2009;47:1-4.

21. Zhou J, Jaquet A, Bissagenene E. Short-term risk of anaemia following initiation of combination antiretroviral treatment in HIV-infected patients in countries in sub-Saharan Africa, Asia-Pacific, and central and South America, J Int AIDS Society 2012;15:5.

22. Subbaraman R, Devaleena B, Selvamuthu P, et al. Factors associated with anemia in HIV infected individuals in Southern India. Int J STD AIDS 2009;20:489-92. 